SHS Web of Conferences 17, 01014 (2015)

DOI: $10.1051 /$ shsconf/ 20151701014

(C) Owned by the authors, published by EDP Sciences, 2015

\title{
Problem and Improvement of Fair Value in the Perspective of Financial Crisis
}

\author{
Caihua Ma, Boquan Li \\ Jiangsu University of Science and Technology, 212003, Zhenjiang, Jiangsu, China
}

\begin{abstract}
Fair value is a kind of value estimation mode. But with the breakout of financial crisis, people started to doubt the impact of this value estimation mode. This article starts with the disputes from various parties about the fair value in the financial crisis, introduces the background of financial crisis and analyzes the manifestation problem of fair value based on the facts that the fair value has an effect of risk amplification and its measurement intensifies the fluctuation of enterprise business performance. Then it also proposes some corresponding countermeasures to perfect the measurement property of fair value based on the confirmation of the fair value measurement.
\end{abstract}

Keywords. fair value measurement; fair value; problem and countermeasure

\section{Introduction of the background of financial crisis}

With the declaration of bankruptcy protection application from the New Century Financial Corp-the second large American sub-prime mortgage company on April 2, 2007, the sub-prime mortgage crisis swept the America. Consequently, a huge turbulence appeared in the financial market. The Bearsden, an American investment bank, was purchased; the Fannie Mae and Freddie Mac was taken over by the American government; AIG fell in a financial crisis and UBS was subject to massive layoffs and faced with financial deficit. Tons of enterprises declared great loss or bankruptcy at the same day, which aggravated the financial crisis. At that time, many financial institutions had a doubt about the fair value measurement. Some bankers and financiers thought the accounting standard of fair value had intensified the crisis. They pointed out that because of the requirement of fair value measurement, many companies had to confirm the great loss that had not happening yet on the account book, which further induced considerable deficit in the enterprises and reduced the business performance and credit rankings, among other things. While in the financial market with limited ration, all those mentioned above directly influenced the investor's confidence. They might refuse to invest or sell the existent investment, leading the company to face a more serious financial strain and forcing them to conduct a second counting, drawing and depreciation. The repeated process made many companies declare bankruptcy and intensified the financial crisis. So, the governments in various countries successively released several expedients in a positive manner to slow down the great reduction in the financial assets book due to the crisis, including the modification of valuation rules for "fair value" ${ }^{[1]}$. We are careful about formulating a new method of using the accounting standard and have fully considered the current situation of enterprise development in China, especially some hot-spot phenomena, such as real estate 
investment and financial products, which provides a certain degree of flexibility, allows for mutual selection and specifies that the method of fair value measurement can only be used based on sustained reliability. In principle, the financial crisis is not an accounting but an economic problem. The fair value just plays a role in reflecting the enterprise assets and liability values in an objective way. It's not a maker of this crisis. In facing with the financial crisis induced by sub-prime mortgage crisis, what we may consider first shall be the fundamental problems such as financial deregulation, assets bubble, improper credit supervision and the lack of business ethics, and then we shall try to consider the perfection of fair value to make it better in reflecting the assets value in special conditions instead of totally denying the fair value. The author thinks we shall discover some problems in the fair value measurement and take measures to make perfection.

\section{Measurement problems of fair value in the financial crisis}

\subsection{It is difficult to actually operate the fair value measurement}

To implement the fair value measurement, the primary problem we may face is how to get the fair value information through some channel and method in a way as reasonable as possible, in order to ensure the reliability of relevant accounting information and avoid the impact of subjective factors on the financial information about the enterprise. In most cases, the fair value is required to be estimated and verified instead of being accessed directly. Meanwhile in the actual work, the accountants shall not only study the value estimation technology and method, but also need to make more professional judgments, which directly increases the difficulty of accounting calculation. So in many cases, the fair value remains hard to be accessed despite the rapid development of market economy in China. The observable transaction prices of many accounting elements, such as assets and liabilities, are difficult to find, so the complexity of present value measurement is also the difficulty in the release and application of fair value measurement mode.

\subsection{Fair value measurement intensifies the fluctuation of enterprise business performance}

In the price measurement, we shall take into account the changes in market environment, environment credibility and risk degree, because they will induce the changes in the assets or liability projects of enterprise, namely the fluctuation of enterprise statement item. According to the new standard, the changes in the fair value of transactional financial assets and financial liabilities in different balance sheet dates will be confirmed as the current profit. As the transactional financial assets and financial liabilities are sensitive to the changes in the exchange rate, interest rate and transaction price, which may induce a great fluctuation of business performance in different accounting periods in the enterprises and financial institutions with a large amount of financial assets a financial liabilities. Theoretically, if there's a fluctuation, it may be reflected in the statement so as to provide more relevant information about the decisions ${ }^{[2]}$. But the fluctuations induced by some factors may have not much relevance, and the response to those fluctuations may mislead the users of statement. This phenomenon is outstanding especially in the breakout of financial crisis.

\subsection{Fair value amplifies the instability of financial market}

The accounting standard "marked-to-market" requires the enterprises to determine the book value of relevant assets in the balance sheet according to the current market price and to replace the historical costs accounting in the past. According to the regulations in the "fair value" measurement, in the huge decline of market and in the absence of market pricing function, the financial products owned by the enterprises caused the financial institutions to excessively write 
down the assets based on the market price, induced loss, reduced the assets adequacy, and further propel the financial institutions to sell off the assets and made the market fall in a vicious cycle of transaction price reduction-assets write-down-assets reduction after audition-sell-off in panicfurther decline of price, which intensified the financial crisis. In the financial crisis, the role it plays in helping to rise and preventing from decline intensified the instability of financial market, and meanwhile the enterprises were hard to seek finance in the situation of assets depreciation and profit decline, which intensified the financial distress.

\subsection{Reliability of fair value measurement is hard to be ensured}

The reliability problem of fair value is always being disputed. The reliability and relevance are the most important two quality features for the accounting information, and the decline of either one will induce the increase of the other. The fair value measurement has a higher relevance than a single historical costs measurement, but with slightly lower reliability. The fair value is a judgment made by both parties in the transaction about the price value. Due to the instability of market environment, some of the accounting items can be confirmed or found with a similar transaction price, but the other can only be estimated instead of being discovered. Because of confidentiality rules, information block and other factors for the business secret, it is fairly difficult to obtain the fair value and judge its fairness, which to some extent influences the objectiveness of accounting data and greatly reduces its reliability ${ }^{[3]}$.

\subsection{Low business quality of accountant}

In the fair value measurement, the book value of a particular asset or liability is determined mostly through estimation of cash flow. As that cash flow generally happens in one or more periods in the future, and the currency has a time value, it becomes inevitable to introduce the present value technology in the measurement. There are several important problems that shall be solved in the measurement process of present value technology, such as estimation of future cash flow, determination of discount rate and selection of price estimation method. In the arrangement and analysis of those external and internal information, the selection and use of relevant parameters used in assets pricing and quantization of assets risk, the accountants will have different degrees of subjectivity, so it largely requires a professional judgment from the accountants.

In the current society with rapid economic development, the promotion focus of people is more and more apparent. The accountants are easy to lose their morality and professional ethics before the huge temptation from the profits. Driven by the interests from an individual or a small group, some of the accountants lose their accounting integrity, make up the estimation of assets value, refuse to disclose the detailed and real information, underestimate the loss, overestimate the profit or even deliberately forge something, which make the accounting information twist the economic activities, distort the accounting matters and seriously influence the quality of accounting information.

\section{Countermeasures to perfect the measurement property of fair value and its effect}

Undoubtedly, the fair value measurement mode intensified the financial crisis to some extent. But it does not mean the fair value accounting is not scientific. The fair value connotation is not to be adjusted. Instead, we may establish an efficient mechanism to adjust the operation mode by which the fair value is determined in an abnormal and invalid market ${ }^{[4]}$. Meanwhile, we may strengthen the investor's confidence in facing the crisis, reduce their panic and reasonably avoid the risks. Therefore, the author thinks it is necessary to establish a framework system for the accounting 
measurement of fair value based on the lesson learned from the fair value measurement in the American sub-prime mortgage crisis.

\subsection{Create and perfect the market environment for the application of fair value}

The fair value measurement is rooted in a perfected market environment, so the establishment of a uniform orderly transaction market with full competition is a premise to introduce the property of fair value measurement. Only in such a market can the fair value information be better disclosed in a more detailed and hierarchical way in order to help the information user to understand the impact of fair value on the enterprise statement. Specifically:

Firstly, we shall invest more in the construction of market economy and establish a perfect market system in China. Our Chinese current market environment is in urgent need to perfect the capital market, expand the bonds market, bill market, foreign exchange market, gold market and other precious metal markets, establish capital goods market and second-hand transaction market with full competition, especially the real estate market and financial tool market, for the purpose of making the foreign exchange obtainment more objective, timely and economic.

Secondly, we shall break the industrial monopoly, reduce the access conditions in the industries such as finance, telecommunication, energy and electricity, allow the private capital to enter the finance, insurance and other fields; meanwhile, we shall fully introduce the market competition mechanism, encourage mixed operation and break the limitation of divided operation. Thirdly, we shall normalize and restrain the governmental behavior to ensure lawful administration of government and make the enterprise a real autonomic and free market transaction body, as well as ensure the realization of fairness in market price.

Thirdly, we shall establish a national information data network for market price and a market information database to greatly facilitate the publicity and real-time of price information and to make it easier for the enterprise accountants to select the proper data when using the fair value to price the assets. Input the realized income, reward rate, costs, price, output, sales and other conditions of each enterprise over the years to the market information database to be used for prediction of future cash flow. The historically realized income of the enterprise is always an important basis to predict the future income. The data of past cash flow in the database may be used to predict the future cash flow so as to transform the complex technology into an easy one.

Meanwhile, we shall establish an authoritative institution for assets assessment. For the assets with different use value, service life, measurement and many varieties, we shall apply the value estimation technology which requires to be used by professional technicians with high specialty in a professional assessment institution with the help of a certain technical means and market parameters. The assessed value shall be recognized by the society, so it is urgent to establish an authoritative institution for assets assessment.

\subsection{Make every effort to ensure the reliability of fair value measurement}

Currently, the reliability of fair value measurement is doubted by many, and it requires a long time to explore and summarize the experience, but the enterprise accounting standard system in China has given full consideration in our national conditions, conducted careful improvement and stipulated several standards for the reliable measurement of fair value when determining the application scope of fair value: (1) The assets with active market shall determine the fair value based on the transaction price in the market; (2) The assets without active market shall determine the fair value based on the transaction price of similar assets; (3) The assets without homogeneous or similar assets comparable to the assets of market transaction shall determine the fair value using value estimation technology ${ }^{[5]}$.

Meanwhile, the enterprise justifiably shall inform the investors and other relevant interested parties of the detailed reasons and background for the measurement when using the fair value meanwhile. The disclosed content shall include: 
(1) Interval of the transaction price for each project. The balance sheet reflects the concept of time point. But the fair value basically lays emphasis on the price estimated in the intentionally concluded current transaction in a fair and rational state for both transactional parties. So it shall be a dynamic concept in the long run. While, based on the periodicity assumption, the enterprise shall provide the statement according to the time point, and the disclosed balance sheet information is definitely a measurement feature in a particular time point. Especially for the assets or liabilities with active market, such as transactional financial assets, the enterprise shall not only provide the fair value estimated according to the accounting standard in the balance sheet date, but also disclose the trend distribution of the transaction price of those assets and liabilities in their existence period or the accounting period to which they belong.

(2) Analysis on sensitiveness. It is to disclose the possible change of fair value and its impact on the company's profit and loss as well as on the owner's equity on the assumption that the relevant risk variables in the balance sheet date have been changed in a reasonable and possible manner. For example, it is more feasible to make an analysis on the sensitiveness of derivative financial tools than to purely disclose its nominal value or fair value ${ }^{[6] .}$ It takes into account the impact of the changes in the interest rate, exchange rate and other factors on the position value of derivative financial products owned by the investment subject. Similarly for other projects of assets and liabilities, the enterprise can also use different value estimation technologies and methods to set up a model among various factors with determined fair value and make an analysis on its sensitiveness.

\subsection{Prepare a comprehensive income statement, carefully use the mixed measurement mode and avoid great fluctuation in the statement items}

To avoid the fluctuation of some items in the enterprise statement due to the application of fair value, we shall introduce a concept of comprehensive income to prepare the comprehensive income statement. The comprehensive income is a broad concept of income, including the confirmed and realized, or confirmed but not realized profit and loss. To prevent the enterprise from manipulating the profits by using the fair value, we shall respectively appraise the unrealized profit and loss and the realized income, as well as increase the disclosure of information related to the fair value ${ }^{[7]}$.

It is hard for the fair value to reflect the true features of the assets that have no active market and whose value is difficult to be estimated. It will even induce serious deviation of value. By comparison, the value of assets or liabilities will present a little fluctuation if priced by the historical costs. Therefore, we shall integrate the advantages of various measurement properties. The financial assets shall be measured according to the fair value, while the financial liabilities shall be measured according to the historical costs. The mixed accounting measurement mode combining the principles of fair value and historical costs can solve the measurement problems in the derivative financial tools, eliminate the disadvantages of fair value and historical costs, overcome the defects in the single measurement principle for the traditional financial statement, and efficiently avoid the fluctuation of financial information due to the value measurement property.

As for the statement and disclosure of fair value, we may prepare the comprehensive income statement according to the principle of fair value as many countries and organizations do. We can prepare the profit statement according to the principle of historical costs or prepare the comprehensive income statement according to the principle of fair value, which may not only provide overall information for the statement users, but also avoid the great fluctuation of income in the profit statement. Furthermore, the statement users may also have a deeper understanding about the business situation of the company by comparing the ending net income in the profit statement with the ending comprehensive income in the comprehensive income statement.

\subsection{Try to improve the business and moral quality of the accountants}


Constantly making more investment in the education and cultivating accountants that hold fair value conception, understand the theory and practice and have noble professional ethics are the necessary conditions for the comprehensive application of fair value, and also the premise to reduce the costs of fair value measurement and apply the fair value. We shall focus on the training and supervision of business quality and professional ethics, increase the study and publicity activities for the new standards and strengthen the application of electronic accounting in the practice. Only in this way, the fair value measurement can be ensured to be properly implemented in the practical work.

\subsection{Effect of reliable fair value measurement}

Through combined facilitation of the enterprises, societies, countries and individuals, the fair value measurement can impose a good effect; it may timely reflect the change in the assets and liabilities to agree with the demand for financial innovation; it may reflect the estimated net present value of future cash flow directly or indirectly contained in the financial tools for the market, which is conducive to the calculation and innovation of financial tools; it may take the reality and future into account to face the risks and uncertainty in a reasonable way, and to provide reliable accounting information for the decision makers. It is believed that with the constant development of economic situation, gradual perfection of economic environment and the ceaseless exploration by a wide range of workers in the accounting theory and practice, the theory of fair value measurement will be continuously improved, and the fair value measurement is sure to be widely spread.

\section{References}

1. Xie, S.F. Fair Value: Research on the International Frontier Accounting Problems. [M] Hunan People's Publishing House, 2004.

2. Zhen, G.F. Research on the Problems in the Application of Fair Value in China and Its Countermeasures [J] Audit Monthly, 2007, 48 49.

3. Shen, Z.K. Discussion about the Relevant Problems in the Application of Fair Value Measurement [J] Communication of Finance and Accounting, 2009, 2.

4. Wang, J.C., Hu, Z.G. Discussion and Analysis on the Current Situation of Fair Value Measurement Research in China and its Relevant Problems [J] Accounting Research, 2007.

5. Li, C.Y., Zhao, X.Y. Discussion on the Application of Fair Value Measurement in China [J] Market Weekly, 2006.

6. Zhao, H. Manifestation Problems of Fair Value in the Financial Crisis and Its Perfection [J] Research of Financial and Accounting, 2011.

7. Zheng, Z.R. Application of Fair Value Application in the Post Financial Crisis in China [J] Journal of Liaoning Medical College, 2011. 